\title{
REMOVAL OF TOXIC METALS FROM AQUEOUS SOLUTION BY SAW DUST
}

\author{
Muhammad B. Ibrahim \\ Department of Pure and Industrial Chemistry, Bayero University, P. M. B. 3011, Kano, Nigeria \\ Email: bashirmbi2@yahoo.ca
}

\begin{abstract}
In this work, feasibility studies of using a natural and low cost adsorbent; saw dust for the removal of $\mathrm{Cr}(\mathrm{VI}), \mathrm{Ni}(\mathrm{II}), \mathrm{Fe}(\mathrm{II})$ and $\mathrm{Cd}(\mathrm{II})$ from aqueous solution was carried out. The efficiency of the adsorbent was judged from the variation of the \% adsorption with (i) contact time, (ii) adsorbent dose, (iii) initial metal ion concentration, (iv) effect of pH variation of the adsorbate solution, (v) activation of the adsorbents and (vi) particle size. Changes in the concentrations of the metallic ions after the adsorption process were monitored using Shimadzu AA650 Double-Beam Digital Atomic Absorption/Flame Spectrophotometer. Results suggest that the adsorbent employed in this work have the ability to remove the tested ions from their aqueous solutions with adsorption order onto the adsorbent varying according to $\mathrm{Cr}>\mathrm{Fe}>\mathrm{Ni}>\mathrm{Cd}$. Also for each ion there is an optimum pH for maximum adsorption beyond which the efficiency declined.
\end{abstract}

Keywords: Saw dust, adsorption, adsorbent, metal ion, \% removal

\section{INTRODUCTION}

Pollution can simply be defined as a harmful change in the natural environment caused by human activities. This may be as a result of the release of substances, which are toxic to either animals or plants, or it may be the release of energy (heat, light, radiation, or sound), which interferes with the development of animals or plants. In general pollution is usually harmful to one or more species of animal or plant. A pollutant on the other hand is any substance produced by human activities which, at an unacceptable level, causes damage to the environment or is harmful to living systems. As such, in order to maintain a healthy living environment, a careful study on the sources and nature of pollution and the ways of pollution control should be considered (Wong et al., 2002).

Water is one of the abundantly available substances in nature and it is distributed naturally in different forms, such as rainwater, river water, spring water and mineral water. Of these categories, rainwater though associated with some dissolved gases like $\mathrm{CO}_{2}, \mathrm{SO}_{2}, \mathrm{NH}_{3}$ etc is believed to be the purest. Water is an essential ingredient for the survival of any form of animal and plant life (Sharma, 2006). On average, a human being consumes about 2 litres of water everyday. Water accounts for about $70 \%$ of the weight of a human body, while about $80 \%$ of the earth surface is covered by water. Out of the estimated 1,011 million $\mathrm{km}^{3}$ of the total water present on earth, only $33,400 \mathrm{~m}^{3}$ of water is available for drinking, agriculture, domestic and industrial consumption. The rest of which is locked up in oceans as salt water, polar ice-caps and glaciers and underground. Owing to increasing industrialization on one hand and exploding population on the other, the demands of water supply have been increasing tremendously. Moreover, considerable part of this limited quantity of water is polluted by sewage, industrial waste and a wide array of synthetic chemicals (Dara, 2006).Water pollutants can be divided among some general classifications into organic pollutants, inorganic pollutants, suspended solids and sediments, radioactive materials and lastly heat. Among these, inorganic pollutants are of most concern for this research.

Chromium as an environmental pollutant enters into the ecosystem by electroplating, metal finishing, chromate preparation, leather tanning etc. The two forms of chromium ions predominantly present in the environment are $\mathrm{Cr}(\mathrm{III})$ and $\mathrm{Cr}(\mathrm{VI})$, in which $\mathrm{Cr}(\mathrm{VI})$ is soluble, toxic and carcinogenic (Ackerley et al., 2004). This fact warrants its regulation in the environment.

Nickel (II) containing wastewaters are common as it is used in a number of industries including electroplating, batteries manufacturing such as $\mathrm{Ni} /$ Fe storage batteries, mining, metal finishing and forging. Also it is used to produce ferrous steel cutlery (Greenwood and Earnshaw, 1993). Higher concentrations of nickel cause cancer of lungs, nose and bone. Dermatitis (Ni Itch) is the most frequent effect of exposure to $\mathrm{Ni}$, such as coins and jewellery. High concentration of $\mathrm{Ni}$ (II) in ingested water may cause severe damage to lungs, kidneys, gastrointestinal distress, e.g., nausea, vomiting, diarrhoea, pulmonary fibrosis, renal edema and skin dermatitis (Meena et al., 2005 and Erdogan et al., 2005). Nickel is genotoxic and mutagenic as well. In industrial wastewaters, nickel concentration varies between 6 and $12 \mathrm{mg} / \mathrm{L}$, which is above safe limit (Bansal and Goyal, 2005).

Cadmium is mainly used in the industry for coating steel, glass and plastics (including polyvinyl chloride), and for nickel cadmium battery production, and automotive tires. It has special importance due to its long half life and it can exert toxic effects on almost all systems of the human body (Tsalev, 1993). 
The main organ for long term cadmium accumulation is the kidney. Here, the half-life period for cadmium is approximately 10 years. A life-long intake can therefore lead to a cadmium accumulation in the kidney, consequently resulting in tubulus cell necrosis (Orlowski and Piotrowski, 2003). The primary targets of the toxic effects of cadmium on liver tissue are hepatocytes and the sinusoidal endothelium (Kayama et al., 1995). At the ultrastructural level, cadmium leads to nuclear condensation and expansion in liver cells. Cadmium could also be shown to be associated with occurrences of ItaiItai, a disease under which patients show a wide range of symptoms such as low grade of bone mineralization, high rate of fractures, increased rate of osteoporosis, and intense bone associated pain (Fridberg et al., 1974; and Nogawa et al., 2004). Cadmium is of special concern because it is non-degradable and therefore persistent; it is highly toxic to humans, plants and animals (Tsezos, 2001).

Iron, although essential to biological systems and very widely abundant in the earth crust, its overload is known as hemochromatosis and is usually caused by a gene that enhances iron absorption. Common symptoms of iron overload include enlarged liver, skin pigmentation, joint diseases, loss of body hair, amenorrhea, and impotence. Untreated hemochromatosis aggravates the risks of diabetes, liver cancer, heart disease and arthritis.

Vast number of work has been reported on the remediation of different toxic metals from the environment. The work of Chaiyasith et al., (2006) explores the feasibility of using treated fly ash for the removal of nickel and cadmium from aqueous solutions using batch adsorption techniques. Their results suggested that the adsorption equilibrium was usually attained within $30 \mathrm{~min}$ at a $\mathrm{pH}$ of $3-5$. The presence of other cations such as lead was found to reduce the adsorption efficiency.

In the year 2009, Bansal et al., assessed the potentials of rice husk for the removal of nickel ions from solution. Their findings showed that the efficiency of the removal depends on the physico-chemical characteristics of the adsorbent, adsorbate concentration and other studied parameters. The efficiency of adsorbent for the nickel removal was found to be $51.8 \%$ for dilute solutions at $20 \mathrm{~g} / \mathrm{L}$ adsorbent dose.

Studies of iron(III) adsorption from aqueous solution by olive cake as an adsorbent was carried out by $\mathrm{Al}$ - Anber and Al - Anber, (2008), in which the influence of the initial $\mathrm{pH}$, temperature, contact time and dosage of the adsorbent on adsorption performance were investigated. Their experimental results show that the kinetic model of pseudo-second order provided a good description of the adsorption process. The biosorption of iron from aqueous solution by dried biomass of activated sludge was also studied by Shokoohi et al., (2009). Their findings revealed that the equilibrium time for iron adsorption onto the biomass was $150 \mathrm{~min}$ and that Elovich kinetic models fits well with experimental data.

Gomes et al., (2001) conducted a study to evaluate the selectivity sequence and estimate the competitive adsorption of several heavy metals in seven Brazilian soils with different chemical and mineralogical characteristics. The sorption affinity of metals for the solid phase, were obtained for each soil and heavy metal cation. On the basis of these, the selectivity sequence were evaluated and the most common were $\mathrm{Cr}>\mathrm{Pb}>$
$\mathrm{Cu}>\mathrm{Cd}>\mathrm{Zn}>\mathrm{Ni}$ and $\mathrm{Pb}>\mathrm{Cr}>\mathrm{Cu}>\mathrm{Cd}>\mathrm{Ni}>\mathrm{Zn}$. Chromium, lead and copper were the cations most strongly adsorbed by the soils, whereas cadmium, nickel and zinc were the least adsorbed in the competitive situation.

The work of Rajmond, 2005 utilised a mixed bed ion exchange column for the simultaneous determination of $\mathrm{Cr}$ (III) and $\mathrm{Cr}$ (VI) using UV detector at a wave length of $365 \mathrm{~nm}$ from environmental samples such as rainwater and galvanic sediments. The performance of his method was established from the linearity, limit of detection, limit of quantification and the influence of sample $\mathrm{pH}$.

\section{MATERIALS AND METHODS}

All glasswares and plastic containers were washed with detergents, rinsed with distilled water and then soaked in a $10 \% \mathrm{HNO}_{3}$ solution for $24 \mathrm{hrs}$. They were then washed with deionised water and dried in an oven for $24 \mathrm{hrs}$ at $80^{\circ} \mathrm{C}$ (Todorovi et al., 2001).

Saw dust was collected from a local sawmill and it was air dried in sunlight until almost all the moisture evaporated, washed several times with distilled water in order to remove the water soluble tannins, after which it was dried in air and then in an oven at $80^{\circ} \mathrm{C}$. The adsorbent was ground to the different working sizes and was kept in a plastic container for subsequent use.

Distilled, deionised water, AnalaR grade reagents were used without further purification for the preparation of all stock solutions, and were kept in a refrigerator. $6 \mathrm{M} \mathrm{HNO}_{3}$ was prepared from conc. $\mathrm{HNO}_{3}$ (specific gravity 1.420 ; percentage purity $65 \% \mathrm{w} / \mathrm{v}$ ) and $1000 \mathrm{mg} / \mathrm{L} \mathrm{Cr}(\mathrm{VI}), \mathrm{Ni}(\mathrm{II}), \mathrm{Fe}(\mathrm{II})$ and $\mathrm{Cd}(\mathrm{II})$ were respectively prepared by dissolving $2.8290 \mathrm{~g}$ of $\mathrm{K}_{2} \mathrm{Cr}_{2} \mathrm{O}_{7}$, $4.0503 \mathrm{~g}$ of $\mathrm{NiCl}_{2} .6 \mathrm{H}_{2} \mathrm{O}, 4.9780 \mathrm{~g}$ of $\mathrm{FeSO}_{4} .7 \mathrm{H}_{2} \mathrm{O}$ and $2.1930 \mathrm{~g}$ of $\mathrm{CdSO}_{4} .8 / 3 \mathrm{H}_{2} \mathrm{O}$ in small volumes of distilled deionised water in separate beakers and the solutions were transferred to a 1.0litre volumetric flasks followed by the addition of $100 \mathrm{~cm}^{3}$ of $6 \mathrm{M} \mathrm{HNO}_{3}$ and they were made to mark with more water (Svehla, 2006). Lower working concentrations were prepared daily from the stock solution by appropriate dilution.

Static adsorption experiments in which the same solution remains in contact with a given quantity of adsorbent till equilibrium between the adsorbate concentration in solution and the adsorbate adsorbed per unit weight of adsorbent is reached was employed in this work. This type of equilibrium established is static in character, as it does not change further with time.

Procedures described by Bhattacharya et al., (2008) and Isa et al., (2008) for testing the effects of variations of adsorbent dose, adsorbate initial concentration, adsorbate $\mathrm{pH}$, surface area and activation of the adsorbent were followed. The extent of removal of the adsorbent and the amount of various metal ions adsorbed onto the adsorbent were calculated from the relations $\left(\frac{C_{o}-C_{e}}{C_{o}} \times 100\right)$ and $q_{e}=\frac{\left(c_{0}-c_{p}\right) x v}{\text {, }}$

where $C_{o}$ and $C_{e}$ are the concentrations $(\mathrm{mg} / \mathrm{L})$ of metal ions initially and at equilibrium time, $w$ is the weight of the adsorbent $(\mathrm{g})$, while $\mathrm{V}$ the volume of the solution in litre (Bhattacharya et al., 2008; El-Nemr et al., 2008; Ibrahim et al., 2006; Wang and Lin, 2008). 


\section{RESULTS AND DISCUSSION}

From Fig.1, it is apparent that by increasing the adsorbent dose the removal efficiency of each metal ion increases. This is readily understood from the fact that the number of available adsorption sites increases by increasing the adsorbent dose and therefore, results in the increase in removal efficiency or the \% adsorption of the respective ion. Also, at a low adsorbent dose, e.g. $2 \mathrm{~g}$, the available sorption sites were quite insufficient compared with the large amount of adsorbate ions in solution, resulting in low removal efficiency. However, at a higher adsorbent dose, e.g. $8 \mathrm{~g}$, the sorption sites were sufficient thereby resulting in a rapid removal of the different adsorbates. The adsorption order of the adsorbates onto the saw dust was observed to follow the pattern $\mathrm{Cr}>\mathrm{Fe}>\mathrm{Ni}>\mathrm{Cd}$.

The strong affinity of the SD adsorbent for $\mathrm{Cr}$ agrees closely with that reported by Baral et al., (2006) for the removal of hexavalent chromium using alumina, goethite, alum sludge and treated saw dust derived from Shorea robusta (Sal). Also the general trend of increase of \% removal with increase in adsorbent dose has been reported by various workers such as Bansal et al., (2009) for the removal of Ni using rice husk.

Initial metal ion concentration is one of the effective factors in removal efficiency. Fig. 2 depicts the effect of the increase in the initial metal ion concentration on the adsorption of the various metal ions onto SD adsorbent. The strong affinities of $\mathrm{Cr}$, $\mathrm{Fe}$ and $\mathrm{Ni}$ the saw dust, give way to a marginal variation in \% adsorption with increase in initial metal ion concentration, leaving $\mathrm{Cd}$ with a linear variation with increase in concentration.

The $\mathrm{pH}$ of aqueous solution and hence wastewater effluents affects a number of reactions that takes place in these solutions. For this reason, in this work the $\mathrm{pH}$ of the test solution was varied from 2 to 10 in order to determine the optimum $\mathrm{pH}$ value for the adsorption of the various metal ions onto the adsorbent. The $\%$ adsorption of the various metal ions analysed with particular reference to $\mathrm{Ni}$ adsorption onto saw dust adsorbent (Figs. 3) shows a gradual increase from $\mathrm{pH} 2$ to 6 and then followed by a decrease. This indicates that there is an optimum $\mathrm{pH}$ value required for the adsorption of the metal ion beyond which a decrease will be experienced.

The observed lower \% removal efficiency at lower $\mathrm{pH}$ may be related to the competition existing between metal ions and $\mathrm{H}^{+}$ions for the available adsorption sites on the adsorbents, while the decrease in the \% removal efficiency after the optimum values has been reached according to Ibrahim et al., (2006) may be attributed to the precipitation of the metals which occur at higher $\mathrm{pH}$ values.

Comparing Figs. 1 and 4, the effect of increase in surface area by using powdered adsorbent on the \% adsorption can be seen. As in the case where powdered adsorbent was used, the \% adsorption for the respective metals onto the adsorbent increased. The same increase (though with some initial decrease) in \% removal efficiency can be observed in Figs. 2 and 5 for a situation where powdered adsorbent was used with increase in initial metal ion concentration. These observed increases are obvious as with reduction in particle size of the adsorbent, the active site available for complexation with metal ions increases thereby leading to improved \% removal efficiency.

Treatment of an adsorbent with acid solution helps in the removal of any debris or soluble biomolecules that might interact with the metal ions during sorption process. This treatment, according to Abia and Asuquo (2006), is called the chemical activation of the adsorbent. Comparing the \% adsorptions of the metal ions from Figs. 1 and 6, a general improvement in the $\%$ removal efficiency is observed. Of particular interest is the \% removal of $\mathrm{Cd}$ ion where almost over $30 \%$ improvement was recorded. This generally may be explained as the activation has made large percentage of the adsorption sites available for the adsorption of the metal ions.

\section{Amounts Adsorbed}

Changes in the amount of metal ion adsorbed on the adsorbent with variation in different parameters studied can generally be summerised as follows;

The metal ion uptake capacity $(\mathrm{mg} / \mathrm{g})$, except for the adsorption of cadmium on saw dust, decreases with increase in adsorbent weight (regardless of whether it is powdered or granular, activated or unactivated) for a fixed adsorbate concentration. This trend was similarly observed by Donmez et al., (1999); and Baral et al., (2006). For all cases where the uptake capacity was judged with variation in adsorbate concentration, it has been found that the amount adsorbed $(\mathrm{mg} / \mathrm{g})$ increases with increase in the initial metal ion concentration until an equilibrium value is reached. This is in agreement with what has been observed earlier by Ibrahim et al., (2006). The pattern of the adsorption behavior with changes in $\mathrm{pH}$ show no difference between those of \% adsorption for the different adsorbates.

\section{CONCLUSSION}

The work has demonstrated the possibility of using Saw dust in the treatment of heavy metal containing effluents. Also surmised in the work is the benefit that would openup to food agriculture and states in Nigeria with abundant wood processing industries in converting waste to wealth. Similarly, the work has attempted to make available for industries, a low cost and efficient method of effluent treatment. 
Bajopas Volume 4 Number 1 June, 2011
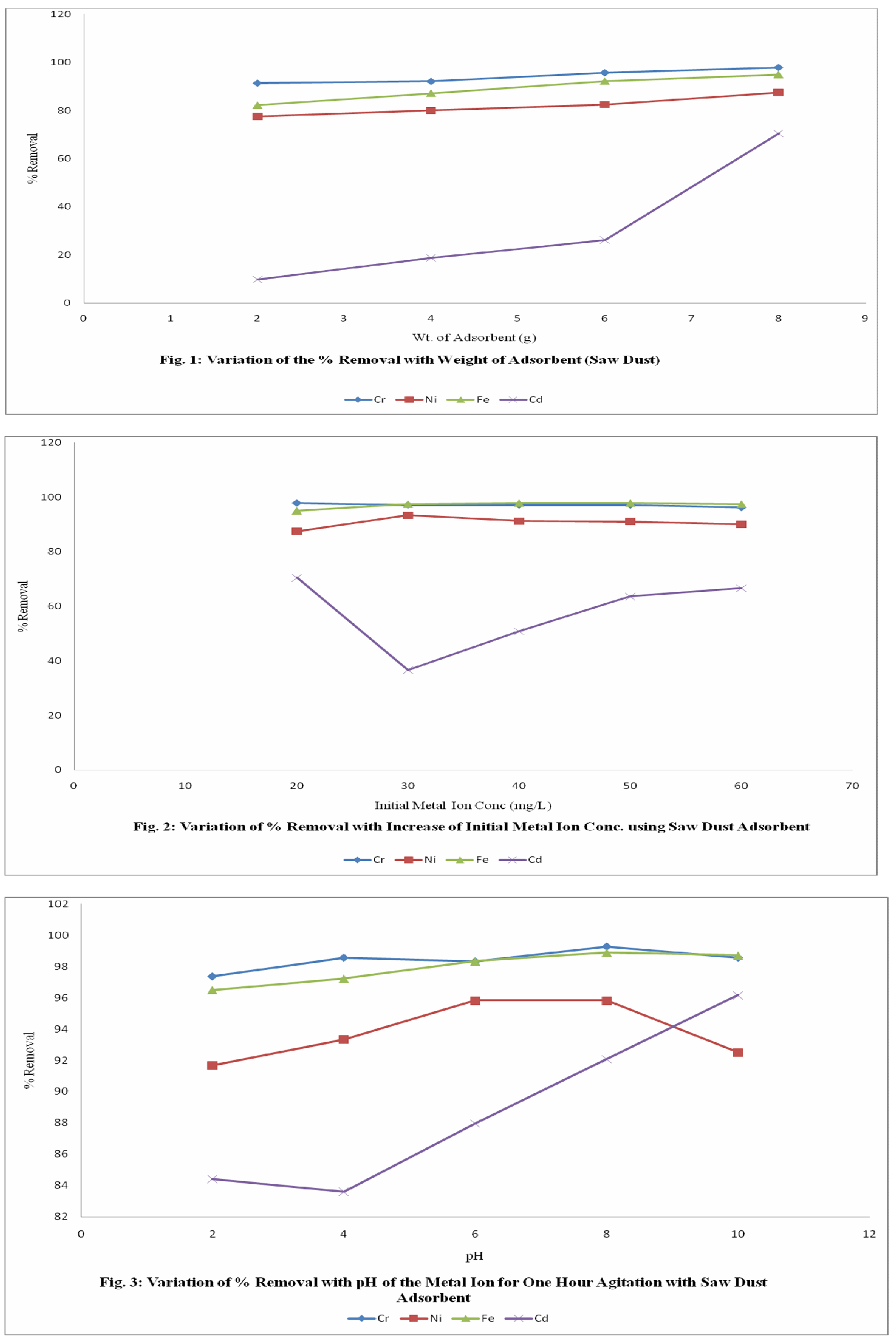
Bajopas Volume 4 Number 1 June, 2011

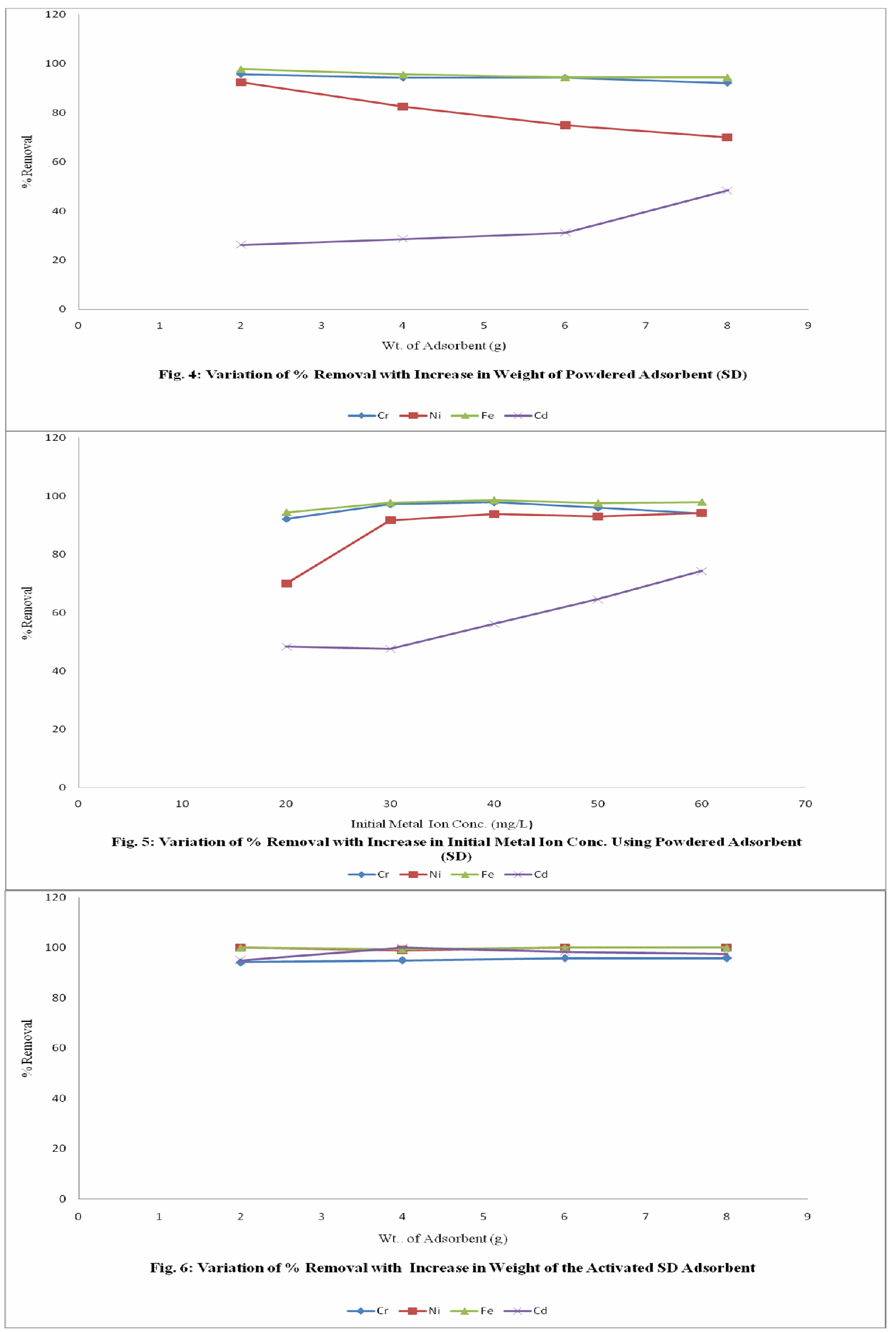




\section{REFERENCES}

Ackerly, D. F., Gonzalez, C. F., Park, C. H., Balke, I. R., Keyhan, M. and Martin, A. (2004). Chromate reducing properties of soluble flavoprotiens from Pseudomonas putida and Escherichia coli. Appl. Environ. Microbiol. 70, p873-882.

Al - Anber, Z. A. and Al - Anber, M. A. S. (2008). Thermodynamics and Kinetic Studies of Iron(III) Adsorption by Olive Cake in a Batch System. J. Mex. Chem. Soc. 52(2):108 - 115.

Bansal, R. C. and Goyal, M. (2005). Activated Carbon Adsorption, CRC Press, New York, p346.

Bansal, M. Singh, D., Garg, V. K., and Rose, P. (2009). Use of Agricultural Waste for the Removal of Nickel Ions from Aqueous solutions: Equilibrium and Kinetics Studies. Proc. Int. Conf. On Energy and Environ., pp228-234.

Baral, S. S., Das, S. N. and Rath, P. (2006). Hexavalent Chromium Removal from Aqueous solution by Adsorption on Treated Sawdust. Biochem. Eng. Journ. 31(3), $216-222$.

Bhattacharya, A. K., Naiya, T. K., Mandal, S. N. and Das, S. K. (2008). Adsorption, Kinetics and Equilibrium Studies on Removal of $\mathrm{Cr}(\mathrm{VI})$ from Aqueous Solutions using Different Low - Cost Adsorbents. Chemical Engineering Journal, 137: 529 - 541.

Chaiyasith, S. Chaiyasith, P. and Septhum, C. (2006). Removal of Cadmium and Nickel From Aqueous Solution by Adsorption onto Treated Fly Ash from Thailand. Thammasat Int. J. Sc. Tech., 11(2):1320.

Dara, S. S. (2006). A Textbook of Engineering Chemistry, S. Chand \& Company Itd., New Delhi, p592.

Donmez, G. C., Aksu, Z., Ozturk, A. and Kutsal, T. (1999). A Comparative Study on Heavy Metal Biosorption Characteristics of some Algae. Process Biochem. 34:885-892.

El-Nemr, A, Khaled, A., Abdelwahab, O. and El-Sikaily, A. (2008). Treatment of Wastewater Containing Toxic Chromium using New Activated Carbon Developed from Date Palm Seed. Journal of Hazardous Materials, 152, pp263-275.

Erdogan, S., Onal, Y., Akmil-Basar, C., Bilmez-Erdemoglu, S.,C., Sarici-ozdemir, C., Koseoglu, E. and Leduygu, G. (2005). Optimization of Nickel adsorption from aqueous solution by using activated Carbon prepared from Waste apricot by chemical activation. Applied Surface Sci., 252, pp1324-1331.

Fridberg, L., Piscator, M., Nordberg, G. F. and Kjellstroem, T. (1974). Cadmium in the Environment, $2^{\text {nd }}$ ed., Chemical Rubber Co. Press, Cleveland, Ohio, p24.

Gomes, P. C., Fontes, M. P. F., da Silva, A. G., Mendonça, E. de S. and Netto, A. R. (2001). Selectivity Sequence and Competitive Adsorption of Heavy Metals by Brazilian Soils. Soil Science Society of America Journal, 65:1115-1121.

Greenwood, N. N. and Earnshaw, A. (1993). Chemistry of the Elements, Pergamon Press, New York, pp404 405.

Ibrahim, S.C., Hanafiah, M. A. K. M. and Yahya, M. Z. A. (2006). Removal of Cadmium from Aqueous Solutions by Adsorption onto Sugarcane Bagasse. American-Eurasian J. Agric \& Environ. Sci., 1(3):179-184.

Kayama, F., Yoshida, T., Elwell, M.R. and Luster, M.I. (1995). Role of tumor necrosis factor- $a$ in cadmium induced hepatotoxicity. Toxicol Appl Pharmacol; 131: 224-234.

Meena, A. K., Mishra, G. K., Raj, P. K., Rajgoapal, C. and Nagar, P. N. (2005). Removal of heavy metal ions from aqueous solutions using carbon aerogel as an adsorbent. J. Harzad. Mater., 122, pp161-170.

Nogawa, K., Kobayashi, E., Okubo, Y. and Suwazono, Y. (2004). Environmental Cadmium Exposure, Adverse effects and Preventive Measures in Japan. Biometals, 17(5),493-498.

Orlowski, C. and Piotrowski, J, K, (2003). Biological levels of Cadmium and Zinc in the small Intestine of nonoccupationally exposed human subjects. Hum. Exp. Toxicol. 22(2), 57-63.

Rajmond, M. (2005). Trace Level Determination of $\mathrm{Cr}(\mathrm{III}) / \mathrm{Cr}(\mathrm{VI})$ in Water Samples using Ion Chromatography with UV - Detection. J. Liq. Chromat. \& Related Tech., 28(18), pp2849-2862.

Sharma, B. K. (2006). Industrial Chemistry, Including Chemical Engineering. Goel Publishing House, Meerut, pp229-237.

Shokoohi, R., Saghi, M. H., Ghafari, H. R. and Hadi, M. (2009). Biosorption of Iron from Aqueous Solution by Dried Biomass of Activated sludge. Iran $\mathrm{J}$. Environ. Health Sci. Eng., 6(2): $107-114$.

Svehla, G. (2006). Vogel's Qualitative Inorganic Analysis, $7^{\text {th }}$ ed., Pearson Education Ltd., India, p139.

Todorovi, Z., Pol, P., Dgordjevi, D. and Autoni, J. S. (2001). Lead Distribution in Water and its Association with Sediments Constituents of the Baije Lake. J. Serb. Chem. Soc. 66(1), pp697-708.

Tsalev, D. L. (1993). Cadmium; in Tsalev DL (ed): Atomic Absorption Spectrometry in Occupational and Environmental Health Practice. Florida, CRC Press, Vol. 1, pp105-112.

Tsezos, M. (2001). Biosorption of metals. The experience accumulated and the outlook for technology development. Hydrometallurgy, 59, pp241-243.

Wang, L. H. and Lin, C. I. (2008). Adsorption of Chromium (III) ion from Aqueous Solution using Rice Hull Ash. Journal of the Chinese Institute of Chemical Engineers. 39:367-373.

Wong, Y. C., Wong, C. T., Onyiruka, S. O. and Akpanisi, L. E.(2002). University General Chemistry, Inorganic and Physical, Africana-Fep Publ. Onitsha, p732. 